\begin{abstract}
"Mircea cel Batran" Naval Academy Scientific Bulletin, Volume XX - 2017 - Issue 1
The journal is indexed in: PROQUEST / DOAJ / Crossref / EBSCOhost / INDEX COPERNICUS I DRJI / OAJI I

JOURNAL INDEX / I2OR / SCIENCE LIBRARY INDEX / Google Scholar / Academic Keys/ ROAD Open Access I Academic Resources / Scientific Indexing Services / SCIPIO / JIFACTOR
\end{abstract}

\title{
LIQUEFILD NATURAL GAS CARRIERS. PRESENT AND FUTURE
}

\author{
Romeo BOSNEAGU ${ }^{1}$ \\ Sorin Marian VASILACHE ${ }^{2}$ \\ Alexandru Nicola RAICIU ${ }^{3}$ \\ ${ }^{1}$ PhD Navigation and Naval Management Department, Mircea cel Batran Naval Academy Constanta \\ Email: romeo bosneagu@yahoo.com \\ ${ }^{2}$ MSc, Mircea cel Batran Naval Academy Constanta \\ ${ }^{3}$ Master Student, Mircea cel Batran Naval Academy Constanta
}

\begin{abstract}
L N G$ \& LPG are the fleet of modern and efficient vessels, all built in the accordance with the most up to date specifications and fitted with new and efficient technology which carry liquefied natural gas and liquefied petrol gas all around the world. The companies which own those vessels operate in ways that balance economic, environmental and social considerations in a responsible way. Their sustainability performance is ranked in some leading index. They maintain the strong investment in projects that will deliver energy resources for decades to come. They also continued to work to reduce the impact on the environment, to respond transparently to the views of their neighbors and to generate jobs and business opportunities for local economies.
\end{abstract}

Keywords: LNG \& LPG ships, liquefied product characteristics, gas carrier characteristics and design

\section{Introduction}

Transportation of liquefied gas at sea started in 1934 by converting two ships transporting oil products to transport liquefied petroleum gas vessels under pressure, thereby allowing longdistance transport of substantial amounts of refined oil products used mainly for consumer use.

Interest in the use of natural gas began to grow in 1990, which led to an increase in orders for ships transporting and thus to increase the world fleet. While the gas market is becoming more attractive, yet specialized vessels in the world fleet number is still relatively small compared to that of ships carrying oil and finished petroleum products.

Liquefied natural gas carriers are often presented in the media as "floating bombs", but accident statistics refute this far. Indeed, the fact that gas is transported in liquefied form in tankers without contact with air or any other source of oxygen, excludes any possibility of explosion.

Thus, there are very few accidents at these types of ships and safety measures encountered in gas transporters are among the most successful. For example, Gaz Fountain, one of the most robust liquefied natural gas carrier, hit by a rocket during the first Gulf War, despite the fact that it had penetrated a tank storage, the ensuing fire was extinguished and the vessel, and the remaining cargo was saved.

Safety systems of ships carrying gas are based on the fact that the merchandise is always kept under positive pressure, which implicitly void air into the system loading / unloading and transfer of goods.
This means that only liquefied gases or vapors may be present, so a flammable atmosphere can not exist in the system. Moreover, larger capacity vessels use a closed system load, no ventilation system for tanks and pipes for loading / unloading dockside vapor when needed.

The quality to maintain the merchandise in an atmosphere that lacks in oxygen and thanks to a system that limits the possibility of liberating gas into the atmosphere, make these vessels to be classified as very safe.

\section{Methodology}

Given the history of the tradition to transport petroleum products, compared to the specialized transport of gas, this document analyzes the peculiarities of liquefied gas and the particularity of each type of gas specialized transport ship relative to oil tankers. The aim is to achieve a comparative study of both the qualities and vulnerabilities, from an operational perspective, but also constructive and operational exploitation with practical purpose for those working in the specialized field of maritime transport. This represents today's gas transport and specialized vessels for this type of transport. Also, based on this information and study of literature and professional experience of the authors, they presented their views on the possible development of new specialized vessels to transport liquefied gas by sea.

\section{Results}

Analysis of statistical data concerning the evolution of the volume transported by sea of liquefied gases worldwide, conducted during 1990-2012 shows a steady increase of over four times (IEA, PFC Energy, 2014), (Figure 1). 
"Mircea cel Batran" Naval Academy Scientific Bulletin, Volume XX - 2017 - Issue 1 The journal is indexed in: PROQUEST I DOAJ / Crossref / EBSCOhost / INDEX COPERNICUS / DRJI / OAJI I JOURNAL INDEX I I2OR / SCIENCE LIBRARY INDEX / Google Scholar / Academic Keys/ ROAD Open Access I Academic Resources / Scientific Indexing Services / SCIPIO / JIFACTOR

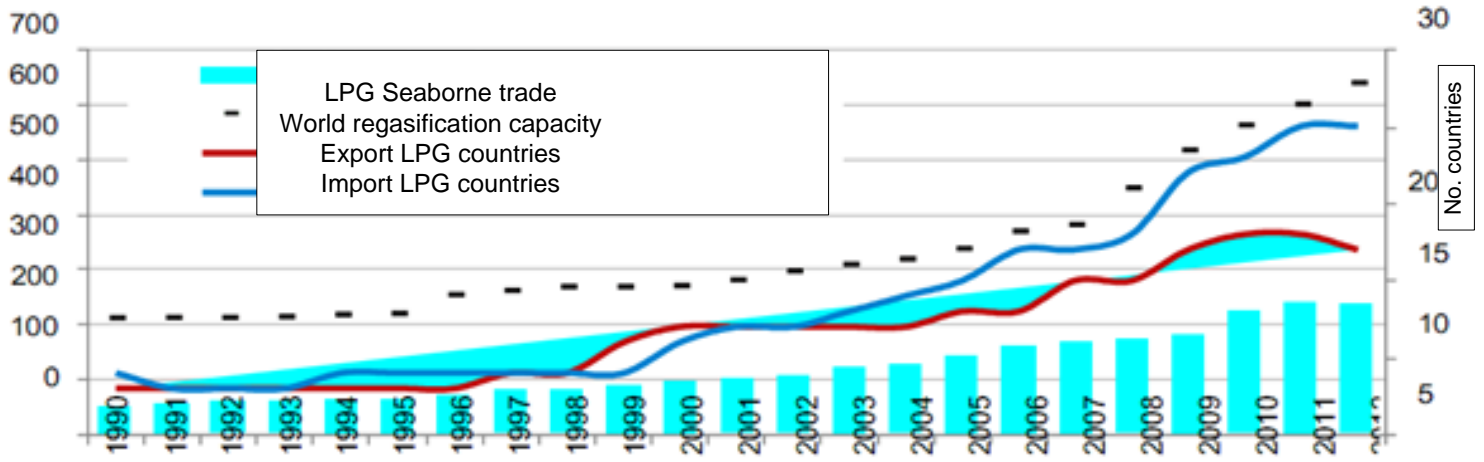

Figure 1. The evolution of the liquefied gases world seaborne trade, 1990-2012

Regarding the analysis of the analytical indicator tone/mile, characterizing the complex evolution of maritime transportation, generally applied to gas seaborne transport, shows a steady increase since 2010, from 576 billion tone-mile, to 1467 billion tone / mile, five times (table 1, and figure 2).

Table 1 The value of the indicator tone /mile for gas seaborne transport, 2000-2015, in billion tone /mile

\begin{tabular}{|c|c|c|c|c|c|c|c|}
\hline $\mathbf{2 0 1 0}$ & $\mathbf{2 0 0 1}$ & $\mathbf{2 0 0 2}$ & $\mathbf{2 0 0 3}$ & $\mathbf{2 0 0 4}$ & $\mathbf{2 0 0 5}$ & $\mathbf{2 0 0 6}$ & $\mathbf{2 0 0 7}$ \\
\hline 576 & 591 & 611 & 662 & 719 & 736 & 833 & 913 \\
\hline $\mathbf{2 0 0 8}$ & $\mathbf{2 0 0 9}$ & $\mathbf{2 0 1 0}$ & $\mathbf{2 0 1 1}$ & $\mathbf{2 0 1 2}$ & $\mathbf{2 0 1 3}$ & $\mathbf{2 0 1 4}$ & $\mathbf{2 0 1 5}$ \\
\hline 956 & 958 & 1147 & 1344 & 1346 & 1347 & 1392 & 1467 \\
\hline
\end{tabular}

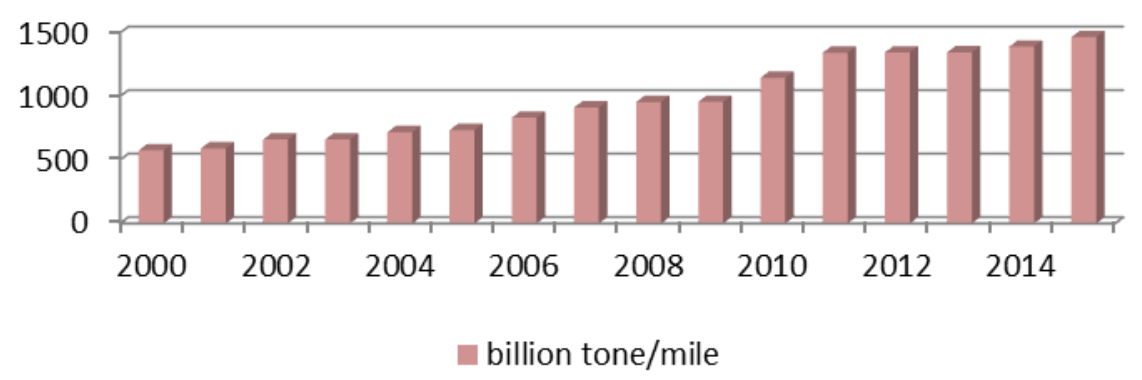

Figure 2 Evolution of the indicator tone/mile for gas transportation by sea, 2000-2015, billion tone/mile

The analysis of the gas transported by sea looks like this:

a.The characteristics of liquefied natural gas LNG

In accordance with the IMO, the definition of liquefied gas is "a substance which is gaseous at ambient temperature and pressure, but which can be liquefied by increasing the pressure or lowering the temperature, or a combination of both methods." Virtually all are liquefied gases and hydrocarbons are naturally flammable. The gas liquefaction process transforms it into a volume adapted to international transport; costs and cargo transport as gaseous would be very high and prohibitive.
The main gases are transported as liquefied natural gas - LNG -LPG and a variety of other gases, all having a specific degree of risk.

Liquefied natural gas, namely methane extracted directly or in combination from the exploitation of oil, is transported in liquid form, a phenomenon which is reached by cooling the gas below its boiling point, process during which certain concentrations of hydrocarbons, water, carbon dioxide, oxygen, and some sulfur compounds are reduced or eliminated. LNG is lighter than water. The main reserves of natural gas are in Algeria, Australia, Brunei, Indonesia, Libya, Malaysia, Oman, Qatar. 


\section{"Mircea cel Batran" Naval Academy Scientific Bulletin, Volume XX - 2017 - Issue 1 The journal is indexed in: PROQUEST I DOAJ / Crossref / EBSCOhost / INDEX COPERNICUS / DRJI / OAJI I JOURNAL INDEX I I2OR / SCIENCE LIBRARY INDEX / Google Scholar / Academic Keys/ ROAD Open Access I Academic Resources / Scientific Indexing Services / SCIPIO / JIFACTOR}

Transporting LNG ships are equipped with double hull specifically designed to manage low temperature of LNG.

When the LNG makes contact with warmer air, creates a vapor cloud visible from condensed moisture in the air. The cloud of vapor, constantly heating, being lighter than air, rises, and when the concentration of gas-air mixture reaches a percentage greater than $5 \%$, it becomes flammable. Not explosive liquid.

LNG is produced both worldwide and domestically at relatively low cost, and the result of the combustion process is cleaner than the diesel fuel. In addition, LNG, used as fuel for engines, achieves a significantly lower NOx and particulate emissions than using oil.

b. Characteristics of liquefied petroleum gas LPG

The second main type of gas is LPG, liquefied petroleum gas. This name covers the products, butane and propane, or a combination of both gases. The transport of these gases is either pressurized or at low temperatures. It can be transported by semi-pressurized ship type. When refrigerated transport - transport butane has a temperature of $-5^{\circ} \mathrm{C}$, propane has a temperature of $-42^{\circ} \mathrm{C}$ transmission, the latter involving the need for temperature to transport tanks of special steels.

As feature is inflammable, generally contain a mixture of hydrocarbon gases used as fuel in heating appliances and vehicles. It is used as the aerosol propellant and as a refrigerant replacing the chloro-fluoro-carbon, in an effort to reduce damage to the ozone layer. When used specifically as a fuel for motor vehicles it is often referred to as auto-gas.

The types of LPG bought and sold include mixes that are composed mainly of propane or predominantly of butane, but most often are mixed, including both propane and butane, depending on the season - in winter more propane, in summer more butane. A powerful odorant - ethanethiol, is added so that leaks can be detected easily. The international standard is EN 589.

GPL is prepared by oil refining and is derived almost entirely from fossil fuels, being manufactured during the refining of petroleum (crude oil), or extract oil or gas deposits. It was produced for the first time in 1910 by Dr. Walter Snelling, and the first commercial products appeared in 1912. It currently provides about 3\% of all energy consumed and burn relatively cleanly without soot and very few sulfur emissions. As a gas, do not pollute water or soil, but can cause air pollution.

The boiling point is below room temperature, so LPG will evaporate quickly under normal conditions of temperature and pressure and is usually provided in containers under pressure. They are typically filled between 80 and $85 \%$ of their capacity in order to allow thermal expansion of the liquid contained therein. The relation between the vaporized gas and the liquefied gas varies depending on the composition, pressure and temperature but is usually about $250: 1$. The pressure at which LPG is liquid, referred to as vapor pressure, vary depending on the composition and temperature is about 220 kilopascals at $20^{\circ} \mathrm{C}$ for butane and propane from about 2.2 megapascals to $55^{\circ} \mathrm{C}$.

LPG is heavier than air, unlike natural gas, and thus will flow along floors and tend to settle in small places such as basements. There are two main dangers in this regard. The first is a potential explosion if the mixture of LPG and air is within the explosion limits and there is a source of ignition. The second is the danger of suffocation, LPG causing air movement, thus leading to a decrease in the oxygen concentration. For that leaks can be detected more easily, it is used freshener mixed with LPG.

LPG can be used as a power source, cogeneration of heat and power. It can be used as the sole source of fuel in the generation of both the electric power and thermal energy. Technology has allowed the GPL to be used not only as fuel for heating and cooking, but also as fuel for electricity generation.

Comparing LPG to natural gas, we can say that LPG consists mainly of propane and butane, while natural gas is composed of methane and ethane. GPL vaporized and at atmospheric pressure has a higher calorific value $(94 \mathrm{MJ} / \mathrm{m} 3$ equivalent $26.1 \mathrm{kWh} / \mathrm{m} 3$ ) than natural gas (methane) (38 MJ / $\mathrm{m} 3$ equivalent to $10.6 \mathrm{kWh} / \mathrm{m} 3$ ), which means that LPG cannot simply be substituted for natural gas.

Commercially available LPG is currently derived from fossil fuels. LPG combustion releases carbon dioxide, a greenhouse gas. The reaction also produces carbon monoxide. GPL, however, releases less $\mathrm{CO} 2$ per unit of energy than coal or oil. It emits $81 \%$ of $\mathrm{CO} 2$ per $\mathrm{kWh}$ produced oil, $70 \%$ of the coal, and less than $50 \%$ of the issued electricity from coal. Being a mixture of propane and butane, LPG emits less carbon / joule than butane but more carbon / joule than propane.

c. Other liquefied products

Ammonia is one of the most common chemical gases in transport by specialized ships and transported worldwide in large volumes, especially for large-scale use in agriculture. Ammonia is highly toxic and requires attention during handling and transportation. Typically, liquefied gas tankers, when carried in bulk, must be used 
"Mircea cel Batran" Naval Academy Scientific Bulletin, Volume XX - 2017 - Issue 1 The journal is indexed in: PROQUEST I DOAJ / Crossref / EBSCOhost / INDEX COPERNICUS / DRJI / OAJI I JOURNAL INDEX I I2OR / SCIENCE LIBRARY INDEX / Google Scholar / Academic Keys/ ROAD Open Access I Academic Resources / Scientific Indexing Services / SCIPIO / JIFACTOR

vessels that comply with the rules defined by the IMO.

A specialized trade sector for Gas is ethylene market and it amounts to about one million tons annually transported by sea on vessels of high technology.

The temperatures used in this case are up to $104^{\circ} \mathrm{C}$ and onboard systems requires probably the highest degree of expertise is highly specialized and automated. Within this group, a sector highly specialized ship is able to carry the multiple gases simultaneously.

Table 2 presents the seriousness of gas compared to oil products, petrol and diesel:

Table 2 Comparison of the degree of danger of gas and oil products

\begin{tabular}{|c|c|c|c|c|}
\hline \multicolumn{5}{|c|}{ Comparison of the degree of danger of gas and oil products } \\
\hline & \multicolumn{2}{|l|}{ Gas } & \multicolumn{2}{|l|}{$\begin{array}{c}\text { Petrol } \\
\text { products }\end{array}$} \\
\hline Danger & LNG & LPG & Benzin & Diesel \\
\hline Toxic & No & No & Yes & Yes \\
\hline Carcinogeni & No & No & Yes & Yes \\
\hline Asphyxiating & $\begin{array}{l}\text { Yes (in enclosed } \\
\text { spaces) }\end{array}$ & $\begin{array}{l}\text { Yes (in enclosed } \\
\text { spaces) }\end{array}$ & No & No \\
\hline Others & Low temperatures & $\begin{array}{l}\text { Moderately low } \\
\text { temperature }\end{array}$ & $\begin{array}{l}\text { Irritant, } \\
\text { narcotic }\end{array}$ & $\begin{array}{l}\text { Irritant, } \\
\text { narcotic }\end{array}$ \\
\hline $\begin{array}{c}\text { Flamability } \\
(\%)\end{array}$ & $5-15$ & $2-10$ & $1-6$ & N/A \\
\hline $\begin{array}{l}\text { Storage } \\
\text { pressure }\end{array}$ & Atmosphere & Usually under pressure & Atmosphere & Atmosphere \\
\hline $\begin{array}{l}\text { Action if it } \\
\text { spreads }\end{array}$ & $\begin{array}{l}\text { Evaporated to } \\
\text { form a visible } \\
\text { cloud dissipates } \\
\text { and not explosive } \\
\text { in open spaces }\end{array}$ & $\begin{array}{l}\text { It evaporates to } \\
\text { form an explosive } \\
\text { cloud }\end{array}$ & $\begin{array}{c}\text { Forms a } \\
\text { puddle that is } \\
\text { flammable } \\
\text { and explosive. } \\
\text { If heated }\end{array}$ & $\begin{array}{c}\text { Forms a } \\
\text { flammable puddle }\end{array}$ \\
\hline
\end{tabular}

World fleet of specialized vessels for gas transport by sea, in the years 2015, 2016 was as follows (UNCTAD, 2016) (Table 3 and Figure 3):

Table 3 Global fleet of specialized vessels for gas transportation in 2015, 2016, in dwt

\begin{tabular}{|l|l|l|l|l|l|}
\hline & $\mathbf{2 0 1 5}$ & $\begin{array}{l}\text { \% world } \\
\text { fleet }\end{array}$ & $\mathbf{2 0 1 6}$ & \% world fleet & $\begin{array}{l}\text { Annual } \\
\text { increase }\end{array}$ \\
\hline Gas carriers & 49699 & $2,8 \%$ & 54469 & $3,0 \%$ & $9,7 \%$ \\
\hline Chemical tankers & 42457 & $2,4 \%$ & 44347 & $2,5 \%$ & $4,43 \%$ \\
\hline
\end{tabular}

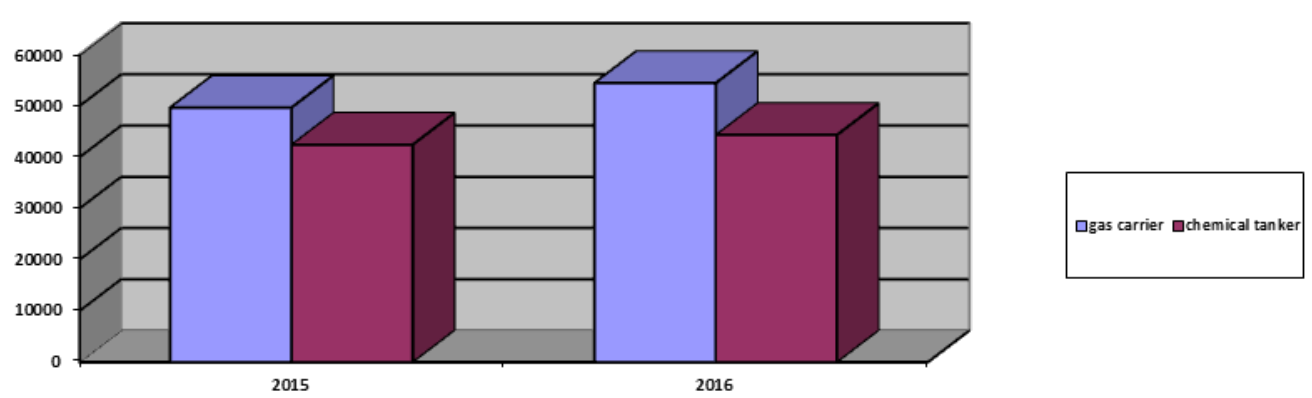

Figure 3 Evolution of the fleet of specialized gas vessels, 2015, 2016, in dwt Analysis of the technical characteristics of ships carrying current gas looks like this: 


\section{"Mircea cel Batran" Naval Academy Scientific Bulletin, Volume XX - 2017 - Issue 1 \\ The journal is indexed in: PROQUEST / DOAJ / Crossref / EBSCOhost / INDEX COPERNICUS / DRJI / OAJI I JOURNAL INDEX I I2OR / SCIENCE LIBRARY INDEX / Google Scholar / Academic Keys/ ROAD Open Access I Academic Resources / Scientific Indexing Services / SCIPIO / JIFACTOR}

a.The regulations for design and construction of ships carrying gas comes from practice models coded by IMO. They were drafted with the assistance of experts in the field, particularly

those who have been working to design and build such ships. This led to the establishment of more rules and a series of recommendations. Starting in June 1986, vessels are built according to the International Code for the construction and Equipment of Ships Carrying Liquefied Gases in Bulk (IGC Code). This code defines transported gas properties and the documentation that the ship must possess the certificate of conformity for the transport of liquefied gases in bulk, and not least the type of cargo the vessel can carry.

Because the pressurized gas transport fleet involves storing cargo tanks and in adjacent compartments in the hull ships transporting gas being built double hull and hull structure and the distance between the inner and outer body are defined in the code mentioned above.

These spaces inserted as an important safety of the ship in a collision or stranding, with disastrous consequences. Outcome of the investigation of a series of collisions when drafting the code led to the conclusion that introducing mandatory building double hull vessels.

In fact, the liquefied gas storage system on board vessels - cargo tanks - are usually compact separated from the structure, making this the main difference between tankers carrying liquefied gases and oil tankers and chemicals.

Also, simultaneously, a code was developed (GC) for vessels built during 1977-1986, namely safety code for construction and equipment of ships carrying liquefied gases in bulk.

b. Classification of gas carriers is as follows (table 4):

Table 4 Liquefied Gas carriers classification

\begin{tabular}{|c|c|c|c|c|}
\hline \multicolumn{5}{|c|}{ Liquefied gas carriers } \\
\hline LPG carrier & $\begin{array}{c}\text { Semi refrigerated liquefied } \\
\text { petrol gas } \\
\text { carrier }\end{array}$ & $\begin{array}{c}\text { Ethylene - Full } \\
\text { chilled carrier }\end{array}$ & $\begin{array}{c}\text { Liquefied petroleum } \\
\text { gas } \\
\text { full chilled carrier }\end{array}$ & $\begin{array}{c}\text { LNG carrier Full } \\
\text { pressurized }\end{array}$ \\
\hline
\end{tabular}

Source: Carriage of liquefied gases -UK P\&l CLUB Magazine, 2013

Cargo tanks, as defined in the code: can be of independent self-supporting or membrane type. Self-supporting tanks may be of type A, B or C.

Fig. 4 LPG carrier 3,200 $\mathrm{m}^{3}$ with cylindric tanks

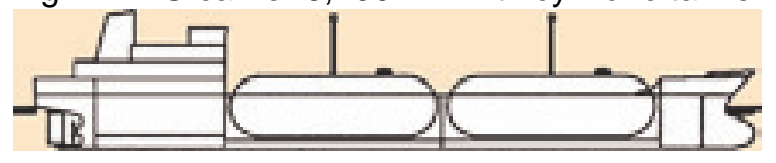

Fig. 5 LPG carrier $78,000 \mathrm{~m}^{3}$ with A-type tanks

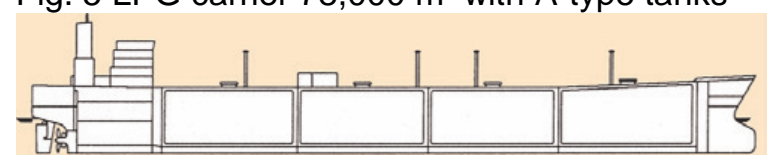

Fig. 6 LNG carrier $35,000 \mathrm{~m}^{3}$ with membrane

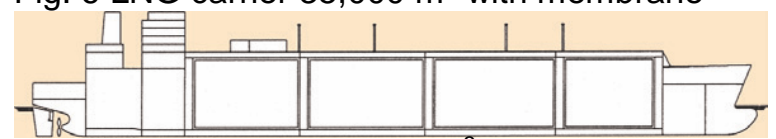

Fig. 7 LNG carrier 137,000 $\mathrm{m}^{3}$ B-type tanks

(Kvaerner Moss system)

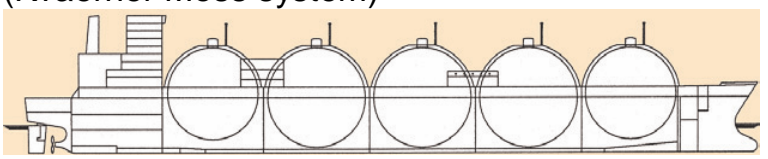

Source: Carriage of liquefied gases -UK P\&I CLUB Magazine, 2013
Tanks type A, Figure 5 prismatic shape - the shape of the magazine.

Tanks type B, Figure 7 usually have a spherical shape, but can be prismatic and are defined as tanks whose performance analysis proved the strength of the material fatigue or crack propagation.

Type C tanks are encountered in ships transporting gas pressure and they are often spherical or cylindrical.

Using one type in favor of another is made depending on the particular area of transport. For example, type $C$ tanker vessels are suitable for the transport of small volume (Figure 4). Therefore, they are most often small capacity ships, coastal shipping in the area. Ships usually have large capacity tanks type A. Type B tanks and tanks with the principle of membrane are generally found in the fleet of LNG carriers (Fig. $6)$.

c. Under pressure gas carrier

These types of vessels are used to transport propane - pressure is approximately 20 bar. Architecture double hull vessel type, the inside tanks containing pressurized. Double bottom and other working spaces as ballast tanks.

These types of vessels are the largest in their class, representing approximately $40 \%$ of the fleet. 


\section{"Mircea cel Batran" Naval Academy Scientific Bulletin, Volume XX - 2017 - Issue 1 The journal is indexed in: PROQUEST / DOAJ / Crossref / EBSCOhost / INDEX COPERNICUS / DRJI / OAJI I JOURNAL INDEX I I2OR / SCIENCE LIBRARY INDEX / Google Scholar / Academic Keys/ ROAD Open Access I Academic Resources / Scientific Indexing Services / SCIPIO / JIFACTOR}

They are generally simple as the design, but solid as the structure and the operating model included the transfer of goods with flexible hose being used especially in the area of China and the transfer of cargo ship to ship, taking merchandise from big tanks refrigerated liquefied gas carriers. Records show that following collision or stranding were lost at sea several tanks in this class, but it was never proven cargo tank penetration. In one case, a ship sunk off the coast of Italy came naturally to the surface as a result of vaporization of goods and regain buoyancy.

Figure 8 presents a small ship, the carrier of pressurized gases ship that we encounter in gas transmission distances relative small coastal shipping, and in Figure 9 is shown a vessel transporting pressurized gas tank shape Cubic.

Fig. 8 Under pressure gas small carrier

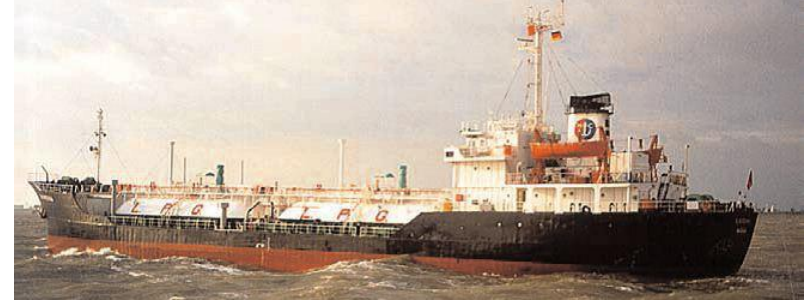

Fig. 9 Under pressure gas carrier ship with cylindrical tanks

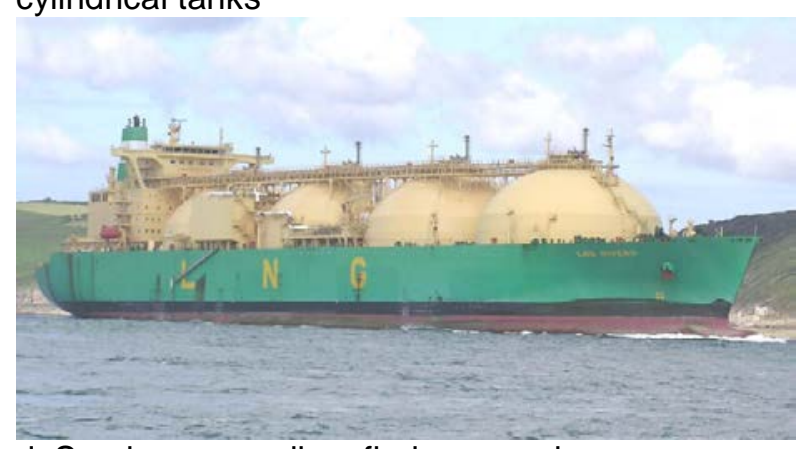

d. Semi-pressure liquefied gas carrier

These types of ship, known as the transportation of semi-refrigerated liquefied gas (fig. 10) have the construction characteristic and transport operation at pressures up to 7 bar. The tanks are made of special steel, bearing low temperature of the cargo. While the tanks are fitted with thermal insulation on the outside to prevent warming of the transported gases, leading to vaporization and need to be liquefied again by being refrigerated and returned to the cargo tanks. Temperature needed to transport goods is maintained by the liquefaction system. These types of ship have a transport capacity of up to $20,000 \mathrm{~m}^{3}$.

Also these vessels bear double hull and protected by ballast tanks in the double bottom, having the quality of being robust and are designed and transport ethylene (Figure 11).

Fig. 10 Semi-pressure liquefied gas carrier

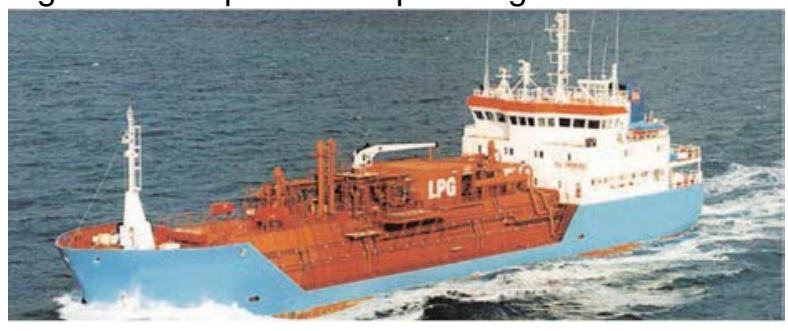

Fig. 11 Ethylene carrier

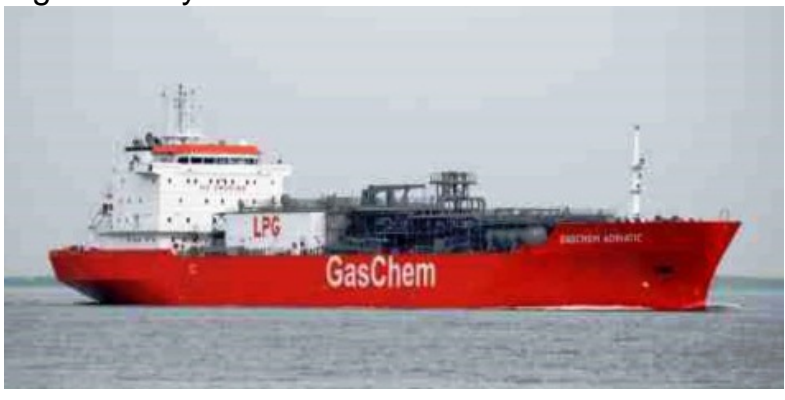

More advanced architecture models enables transport of several types These vessels are relatively few in number but are among the most specialized vessels. The ethylene used as a raw material in the petrochemical industry is used in the production of polyethylene, ethylene dichloride, ethanol, styrene, glycols, and many other products. It is stored in liquefied form completely chilled to $-104^{\circ} \mathrm{C}$. temperature of cargo such as LPG, ammonia, butadienepropylene and vinyl chloride. In order to fulfill the transport function of several varieties of liquefied gas cargo, systems are independent to avoid contamination.

The carrying capacity of this type of ship is 2,000 $\mathrm{m}^{3}$ to $15,000 \mathrm{~m}^{3}$ up, storage tanks are independent -type C-type and can be cylindrical or bi-lobe shape and are constructed of stainless steel. An inert gas generator will be used in the production of dry inert gas, usually cylindrical pressure tanks and drying the semi-pressurized cargo or creating barriers during transport.

d. Full chilled liquefied gas carriers

Are vessels with a carrying capacity of up to about $100,000 \mathrm{~m}^{3}$ (Figure 12). Transported cargo is kept at a pressure close to the environment but at a temperature of up to $-48^{\circ} \mathrm{C}$ liquefaction system is characteristic to these types of vessels, tanks that are provided are made of special steel, resistant to low temperatures. All ships have double bottom and some of them are equipped with lateral ballast tanks. 


\section{"Mircea cel Batran" Naval Academy Scientific Bulletin, Volume XX - 2017 - Issue 1 The journal is indexed in: PROQUEST / DOAJ / Crossref / EBSCOhost / INDEX COPERNICUS / DRJI / OAJI I JOURNAL INDEX I I2OR / SCIENCE LIBRARY INDEX / Google Scholar / Academic Keys/ ROAD Open Access I Academic Resources / Scientific Indexing Services / SCIPIO / JIFACTOR}

All ships of this type are provided with storage tanks protected by a special steel structure adjacent to form a second barrier of protection if it appears a crack the merchandise would seep into adjacent spaces. All storage tanks are equipped with safety valves in case the goods would heat up to a temperature of aeration in the absence of a liquefaction system or a fire.

\section{Fig. 12 Full reefer gas carrier}

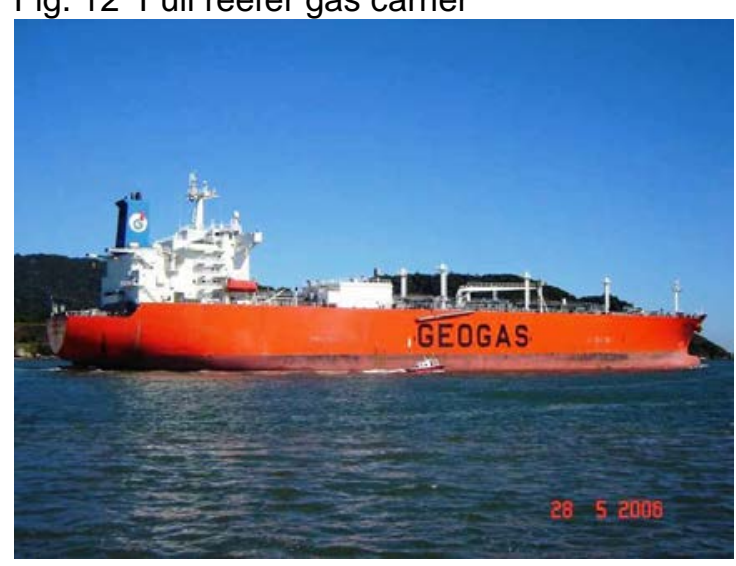

\section{e. LNG carriers}

With few exceptions, LNG carriers (fig. 13) have capacities of between $75,000 \mathrm{~m}^{3}$ and $150,000 \mathrm{~m}^{3}$ forecast to reach up to $265,000 \mathrm{~m}^{3}$. These vessels have insulated cargo tanks and cargo is transported at atmospheric pressure, type spherical tanks being independent, membrane type or prism. In the case of membrane tanks, cargo is stored in stainless steel tanks, heat Isolated. All specialized vessels in the transportation of LNG have double hull, the inner body being sealed and surrounding anchored tankers must have a safety system in case cracks and/or leaks gas capable of containing any loss over a period 15 days. LNG carriers do not liquefy gas, but use it as fuel for boiler.

\section{Fig. 13 LNG carrier}

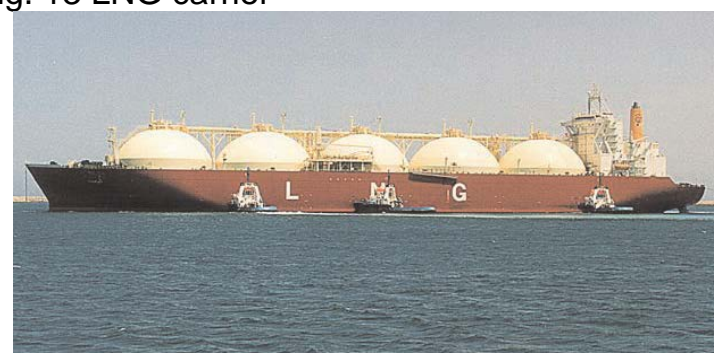

The Future of liquefied gas transportation at sea

The evolution of shipbuilding carrying liquefied gases is spectacular, culminating now with the release on water in December 2013 of the "Prelude" (vessel) owned by Shell Company built in South Korea (fig. 14). Carrier "Prelude" with a length of 488 meters, is 50 meters longer than the building height symbolic of New York, Empire State Building. Fully loaded, the ship's weight reaches 600,000 tons, with a width of 74 meters. "Prelude" is also a platform for extracting liquefied natural gas, which allows Shell to produce natural gas at sea and later to liquefaction by cooling them to a temperature of -162 degrees Celsius, and then transport them around the world. The vessel will be connected to the reserves from the ocean depths using special pipes, which are extracted gas.

After a year or construction, "Prelude" was launched in water at the port Geoje, South Korea. It was designed to withstand a Category 5 hurricane and can anchor at sea even during the strongest cyclone since it has one of the largest of anchoring systems in the world. The vessel has three engines of 6,700 horsepower each.

The official launch of Prelude vessel is scheduled for 2017 and will operate west of Australia for the next 25 years, although Shell Company hopes to be able to find other sources of energy in other parts of the world.

Prelude replaces the vessel Emma Maersk, measuring 397 meters, in the ranking of the largest ships.

Fig. 14 Gas carrier Prelude

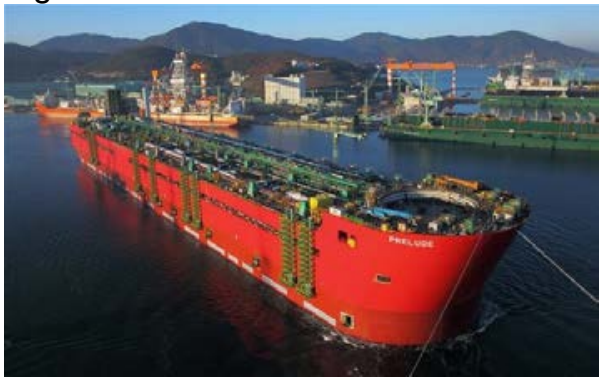

Source: photo Reuters, 2013

\section{Conclusion}

Today, in conditions of interdependence and globalization, the sea transport of liquefied gases, efficiency and profitability, are the engine of economic development and prosperity.

Liquefied gas transport market is driven by energy needs worldwide, the global economy, the demographic situation, industrialization and foremost ,,geography" energy surplus and deficit crisis. 


\begin{abstract}
"Mircea cel Batran" Naval Academy Scientific Bulletin, Volume XX - 2017 - Issue 1
The journal is indexed in: PROQUEST / DOAJ / Crossref / EBSCOhost / INDEX COPERNICUS / DRJI / OAJI I

JOURNAL INDEX I I2OR / SCIENCE LIBRARY INDEX / Google Scholar / Academic Keys/ ROAD Open Access I Academic Resources / Scientific Indexing Services / SCIPIO / JIFACTOR
\end{abstract}

In terms of outlook, profitability coupled with the increasingly obvious motivation for environmental protection inevitably leads to the use of natural gas or liquefied petroleum gas and profitability study inevitably lead to higher long-distance transport.

The current trend in the construction of specialized vessels to transport gas at sea is the increase in tonnage, specialization and degree of operational safety.

The shipbuilding specialized in the transportation of the gas had the biggest increase, $9.7 \%$, higher than the container ships, a trend that will continue in the coming years.

In the near future is also anticipated the release of tankers transporting gas under pressure (Compressed natural gas - CNG), already being designed various models, but due to the low transport capacity and high cost of build from, beginning construction of large capacity can't be provided.

\title{
Bibliography
}

[1]Boşneagu, R., 2017, Geoeconomia trans-porturilor maritime, Editura EX PONTO, Constanta (in Romanian);

[2]Boşneagu, R.,2017, Region. Regionalization. Globalization. The Sea - Territory of Globalization, $4^{\text {th }}$ Edition, The International Scientific Con-ference, Communication, Context, Inter-disciplinarity, Petru Maior University of Tîrgu Mureş, www.upm.ro/cci/CCl-04/vol04-Spi.pdfh;

[3] Bosneagu, R., 2016, International Relations Development Strategies from the Perspective of Maritime Freight Transport Development, Constanta Maritime University Annals, Year XVI, Vol.25, 2016, http://www2.cmu-edu.eu/anale/wp-content/uploads/sites/10/2016/10/Anale-vol.25-2016.pdf;

[4] Boşneagu, R., et al., 2014, Strategic research of the maritime market, The 8th edition of the International Conference on European Integration - Realities and Perspectives, Danubius University of Galați,http://www.conferences.univdanubius.ro/index.php/EIRP/EIRP 2013;

[5] Boşneagu, R., et al., 2014, World economy and world seaborne trade in the 2005 -2013 period, The 9th edition of the International Conference on European Integration - Realities and Perspectives, Danubius University of Galaţi, http://www.conferences.univ-danubius.ro/index. Php /EIRP /EIRP2014;

[6] Brown M., ET AL., Study on LNG Quality Issues, a study for the European Commission - JRC Institute for Energy prepared by Advantica Ltd., Loughborough, UK, 2008;

[7] Coyle D., Reviewing LNG Specifications, Pipeline and Gas Technology, 2008;

[8] Hallouche H., The Gas Exporting Countries Forum: Is It Really a Gas OPEC in the Making, Oxford Institute for Energy Studies, NG 13, June 2006;

[9] Kavalov, B., et al, JRC REFERENCE REPORTS - Liquefied Natural Gas for Europe - Some Important Issues for Consideration, 2011;

[10] Kraus, R., S., Storage and Transportation of Crude Oil, Natural Gases, Liquid Petroleum Products and Other Chemicals, 2012;

[11]Lupu,C., E., Lupu,S., Petcu,A., EB lifetime distributions as alternative to the EP lifetime distributions, Analele Univ. Ovidius Constanţa, Seria Matematică, ISSN 1224-1784, Vol. 22(3), 2014, 115-116;

[12] Lupu, S.,Pocora,A., Boșneagu, R., Katona., The security and safety of maritime navigation through Romanian maritime harbors, "Mircea cel Batran" Naval Academy Scientific Bulletin, Volume XIX - 2016 Issue 2, pag 48-54 DOI: 10.21279/1454-864X-16-I2-007, Constanța 2016

[13] Toacă, I., Exploatarea tancurilor de gaze lichefiate, CPPMC, Constanţa, 2000, (in Romanian);

[14] $]^{\star \star \star}$ Carriage of liquefied gases -UK P\&I CLUB Magazine, 2013;

$[15]^{\star \star \star}$ Drewry Shipping Consultants Ltd., The Drewry annual LNG Shipping Market Review and Forecast 2007-2008, 2007-2013;

[16] ${ }^{\star \star \star}$ EASEE-gas (European Association for the Streamlining of Energy Exchange), Common Business Practice on Harmonisation of Natural Gas Quality, CBP 2005-001/01, Paris, 2005;

$[17]^{\star \star \star}$ European Commission, Directorate-General for Energy and Transport, European Energy and Transport Trends to $2003-2007$ update, 2008;

[18] Federal Institute for Geosciences and Natural Resources (BGR), Reserves, Resources and Availability of Energy Resources 2006, 2007, 2009;

[19] ***Financial Times Ltd., Gas exporters launch pricing study, 09 April 2007;

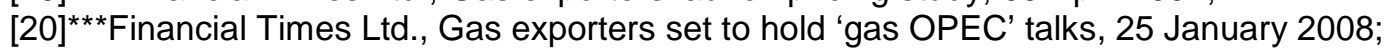

$[21]^{\star \star \star}$ http://www.gecforum.org, Gas Exporting Countries Forum (GECF);

$[22]^{\star \star \star}$ Gas Technology Institute, Final Report on Gas Interchangeability Tests - Evaluating the Range of Interchangeability of Vaporized LNG and Natural Gas, Study GRI-03/0159, April 2003;

[23]*** Global Insight, Global LNG Outlook 2015;

[24] ${ }^{\star \star \star}$ World Investment Report, 2015, UNCTAD;

[25] $]^{\star \star \star}$ World Investment Report, 2016, UNCTAD;

[26] ${ }^{\star \star \star T r a d e ~ a n d ~ D e v e l o p m e n t ~ R e p o r t, ~ 2015, ~ U N C T A D ; ~}$

(c) 2017. This work is licensed under the Creative Commons Attribution-Noncommercial-Share Alike 4.0 License. 
"Mircea cel Batran" Naval Academy Scientific Bulletin, Volume XX - 2017 - Issue 1 The journal is indexed in: PROQUEST I DOAJ / Crossref / EBSCOhost / INDEX COPERNICUS / DRJI / OAJI I JOURNAL INDEX I I2OR / SCIENCE LIBRARY INDEX / Google Scholar / Academic Keys/ ROAD Open Access I Academic Resources / Scientific Indexing Services / SCIPIO / JIFACTOR

[27] ${ }^{\star \star \star}$ Trade and Development Report, 2016, UNCTAD;

[28] ${ }^{\star \star \star}$ Review of Maritime Review, 2015, UNCTAD;

$[29]^{\star \star \star}$ Review of Maritime Review, 2016, UNCTAD 